Article

\title{
The Philippine Church, State, and People on the Problem of Population
}

\author{
F. P. A. Demeterio III
}

I his paper will take a look at six things, namely: 1) the global picture of the population problem; 2) the leading theories on population; 3) the place of the Philippines among the worlds' most populated, densest and fastest growing countries; 4) the contours and behavior of Philippine demographics; 5) the existing power relations amidst the Philippine Church, State, and people concerning the issue of population; and 6) the possibility of a better alternative paradigm of power relations from the encyclical Deus Caritas Est of Pope Benedict XVI.

\section{A Global Picture of the Population Problem}

The problem of over-population is a very recent phenomenon. Human beings have been in existence for the past 200,000 years, but the threat of over-population appeared only in the last 200 years. From the emergence of the first Homo sapiens $(200,000 \mathrm{BC})$ to the invention of agriculture, demographers believe that the human population did not exceed four million. Agricultural Revolution (8,000 BC) enabled the world to support more than four million human beings. Population started to grow more rapidly.

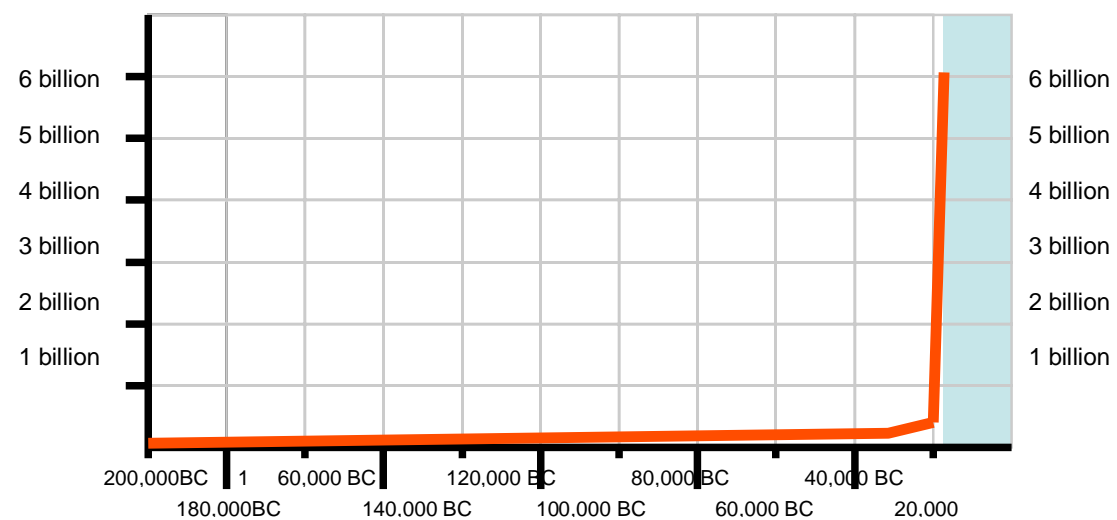

Figure 1: The Global Population Curve from the Emergence of the Homo sapiens to the Present. 1

${ }^{1}$ John Weeks, Population: An Introduction to Concepts and Issues Ninth Edition (Belmont, California: Wadsworth, 2005), 35.

(c) 2007 F. P. A. Demeterio III http:// www.kritike.org/journal/issue 2/ demeterio december2007.pdf ISSN 1908-7330 


\section{THE PROBLEM OF POPULATION}

It took humanity 200,000 years to reach its first billion mark. But the second billion mark was reached in a matter of 100 years; the third in a matter of another 30 years; the fourth in a matter of another 15 years; the fifth in matter of another 10 years; and the sixth in a matter of another 15 years. The very steep curve in figure 1 is what is commonly known as the population explosion. Demographers estimate that in the year 2050, the world will be carrying a population of nine-billion human beings. ${ }^{2}$

What makes the population explosion a problem? This splurge of growth gives jitters to state economists and policy makers for the reason that human beings need resources in order to survive. Since these resources have their limits, a continuous snowballing of the human population would be difficult to sustain and would eventually reach a point where it could no longer be sustained.

We may just take a look at the more basic needs of food, water, shelter and air. As the population increases, agricultural lands are converted to residential use, which entails a reduction of food production. Converting the forest reserves into agricultural lands in order to meet the rising demand for food would not be a wise option because this would cut into the oxygen and water cycles that the same growing population needs.

The picture would become more complicated when we factor in the more sophisticated needs of human beings, such as energy, with its greenhouse effect; education and the shortage of additional schoolhouses; as well as employment with the need to create new jobs. A rapidly growing population strains not only the environment but the society and the government as well.

What is the singular cause of that very steep population increase? The answer to this question would be the tandem of science and technology. Prior to the agricultural revolution, death rate was very high. It is estimated that more than half of the children born at that time could not reach the age of five, and life expectancy was only 20 years. Furthermore, the nomads did not bother to maximize the number of their children. This was because in a hunting-gathering setup, infants, toddlers, and lactating mothers were supposed to be seen as liabilities. After the agricultural revolution, birth rate started to increase as children started to be seen as potential farm hands, defenders of old territories and fighters for new territories. Better and more constant supply of nutrition decreased the death rate, although relatively speaking it still remained high.

It was only after the industrial revolution, when medicine conquered sickness and economic development gave humanity not only better food, clothing and shelter, but also hygiene and education, that death rate started to substantially plummet. Life expectancy rose to approximately 70 years. These things initially happened in the first world countries and spread to the other parts of the world with the colonization process and the aid and welfare

\footnotetext{
2 See "World Population Prospects," in GeoHive Gldbal Statistics, $<$ http:/ / www.geohive.com/ earth/ pop_prospects.aspx >.
} 
movements after the Second World War. It is this high birth rate and low death rate that spawned the population explosion.

\section{The Leading Theories in Population}

How did the intellectuals and experts view this steady and, lately, sudden increase in population? We may study their divergent thoughts against the backdrop of the global population curve:

Moses (circa 1,300 BC), Jewish Patriarch and the acknowledged author of the Torah, made the famous statement: "Be fruitful and multiply." This was definitely written in the context of an under-populated society that is in need of more farmers, herdsmen and warriors. The world population at that time was less than 50 million.

Confucius (circa 551-479 BC), Chinese thinker and social philosopher, still believed in the benefit of a big population, but suggested that the government should intervene to balance the density distribution, as well as the number of people and the available resources. The world population at that time was about 100 million.

Plato (428-347 BC), Greek philosopher, theorized that the quality of population is more important than the sheer quantity. Because he adhered to a democratic form of society, he argued that the city-state should have a fixed population of about five thousand individuals. The world population at that time was about 150 million. His student, Aristotle, even prescribed abortion and infanticide to maintain such a small population ideal.

Marcus Tullius Cicero (106-43 BC), Roman statesman and intellectual, theorized on the importance of a big population for the Roman Empire. Although the world population at that time was about 200 million, modern scholars suspect that the Roman birth rate was in a decline due to a materialistic way of life that had become anti-natalist.

Ibn Khaldun (1332-1406 AD), a Tunisian historian, sociologist and economist, considered population increase as something good as it would result into division of labor and specialization that would reap greater financial income for the individuals. The world population at that time was about 350 million.

Mercantilism, a European economic theory, represented by its leading exponent Jean-Baptiste Colbert (1619-1683 AD ), flourished from 1500 to 1800 AD. Mercantilists believed that an increase in population is beneficial for a nation. During its existence the world population was about 450 to 950 million.

Physiocratism, a European economic theory represented by its leading exponent Francois Q uesnay (1694-1774 AD), flourished from 1700 to 1800 AD. Physiocrats believed that the wealth of a nation is based on the productivity of its land and not on the number of its people. During its existence the world population was about 650 to 950 million.

Thomas Malthus (1766-1834), English demographer and political economist, gave the most controversial and pessimistic theory on population 


\section{THE PROBLEM OF POPULATION}

growth. He emphasized that population grows exponentially, while food production only grows arithmetically. Such an imbalance of growth would bring humanity into a food crisis. At that time the world population was about 950 million. Although he did not recommend contraception, his followers emphasized this as the way to face the threat of over-population.

Karl Marx (1818-1883), G erman philosopher and economic theorist, disagreed with Malthus and pointed out that population growth is not the cause of poverty, but the inequitable distribution of resources. At that time the world population was about 1.2 billion. His followers, however, advocated for an intervention on population growth.

The Demographic Transition Theory, formulated by Frank Wallace Notestein (1902-1983), American demographer, claimed that there are three stages of population change: high birth and high death rates (stable population); high birth and low death rates (increasing population); and low birth and low death rate (declining population). At that time the world population was about 2.5 billion. This theory, however, did not clearly explain why in the third stage the birth rate starts to decline.

The Theory of D emographic Change and Response, as formulated by Kingsley D avis (1908-1997), American sociologist and demographer, attempted to explain why in the third stage of the demographic transition the birth rate starts to decline. Davis stated that individuals respond to the increasing number of population by reducing their intended number of offspring in order for themselves to have a better standard of living and for their children to have better education and chances for the future. At that time the world population was about 3 billion.

Pope Paul VI (1897-1978) published the encyclical H umane V itae. The document was not clear in recognizing global population as a problem. Instead it leans on the Marxist idea that it is not over-population which is the greater problem, but the inequitable distribution of resources. The document unequivocally condemned abortion and artificial contraception as evil. At that time the world population was about 3.5 billion.

Ansley Coale (1917-2002), American demographer, specified that there are three preconditions for a decline in fertility: 1) the belief that rational choice is a valid element of married life, 2) the belief that reduced fertility is advantageous, and 3) the knowledge and mastery of reproductive control. At that time the world population was about 4 billion.

Among the several theorists that this paper had examined, it is noticeable that there are pro-natalists and anti-natalists among them; and some of them are clearly optimistic about the future, while others are pessimistic. Although the global population problem is certainly grave, it is also worth recognizing that the majority of the leading theorists of population are pronatalists and optimistic about the future. 


\section{F. DEMETERIO 101}

\section{The Most Populated, Densest, and Fastest Growing Countries in the World}

How bad is the population problem of the Philippines? We can address this question by first looking into the world's most populated countries. The table below shows that our country stands 14th among the world's most populated countries.

\begin{tabular}{|l|l|l|}
\hline Rank & Country & Population \\
\hline 1 & China & $1,304,000,000$ \\
2 & India & $1,065,000,000$ \\
3 & United States & $294,000,000$ \\
4 & Indonesia & $220,000,000$ \\
5 & Brazil & $178,000,000$ \\
6 & Pakistan & $154,000,000$ \\
7 & Bangladesh & $147,000,000$ \\
8 & Russia & $143,000,000$ \\
9 & Japan & $128,000,000$ \\
10 & Nigeria & $124,000,000$ \\
11 & Mexico & $103,000,000$ \\
12 & Germany & $82,000,000$ \\
13 & Vietnam & $81,000,000$ \\
14 & Philippines & $80,000,000$ \\
15 & Egypt & $72,000,000$ \\
16 & Ethiopia & $71,000,000$ \\
17 & Turkey & $71,000,000$ \\
18 & Iran & $69,000,000$ \\
19 & Thailand & $63,000,000$ \\
20 & France & $60,000,000$ \\
\hline
\end{tabular}

Table 1: The World's 20 Most-Populated Countries as of $2003 .{ }^{3}$

That is not so alarming. But once the idea that the Philippine archipelago is not a very big one is factored in, things can become a little scarier. The table below shows that among the world's most populated countries, the Philippines stands $4^{\text {th }}$ densest.

\begin{tabular}{|c|c|c|c|c|}
\hline Rank & Country & Population & $\begin{array}{l}\text { Land Area } \\
(\mathrm{Sq} \mathrm{Km})\end{array}$ & Density \\
\hline 1 & Bangladesh & $147,000,000$ & 129,500 & 1,135 \\
\hline 2 & India & $1,065,000,000$ & $2,973,320$ & 358 \\
\hline 3 & Japan & $128,000,000$ & 375,550 & 341 \\
\hline 4 & Philippines & $80,000,000$ & 297,850 & 269 \\
\hline 5 & Vietnam & $81,000,000$ & 326,340 & 248 \\
\hline 6 & Germany & $82,000,000$ & 349,650 & 235 \\
\hline 7 & Pakistan & $154,000,000$ & 771,820 & 200 \\
\hline 8 & China & $1,304,000,000$ & $9,326,590$ & 140 \\
\hline 9 & Nigeria & $124,000,000$ & 911,680 & 136 \\
\hline 10 & Thailand & $63,000,000$ & 510,230 & 123 \\
\hline 11 & Indonesia & $220,000,000$ & $1,825,950$ & 120 \\
\hline 12 & France & $60,000,000$ & 551,670 & 109 \\
\hline 13 & Turkey & $71,000,000$ & 769,230 & 92 \\
\hline 14 & Egypt & $72,000,000$ & 994,560 & 72 \\
\hline 15 & Ethiopia & $71,000,000$ & 999,740 & 71 \\
\hline 16 & Mexico & $103,000,000$ & $1,908,830$ & 54 \\
\hline 17 & Iran & $69,000,000$ & $1,636,880$ & 42 \\
\hline 18 & United States & $294,000,000$ & $9,158,240$ & 32 \\
\hline 19 & Brazil & $178,000,000$ & $8,456,350$ & 21 \\
\hline 20 & Russia & $143,000,000$ & $16,889,390$ & 8 \\
\hline
\end{tabular}

${ }^{3}$ Weeks, qp at, 48. 


\section{THE PROBLEM OF POPULATION}

Table 1: The D ensities of the World's 20 Most-Populated Countries as of 2003.4

O ur density of 269 individuals per square kilometer is way above the world density of 48 individuals per square kilometer. Once the idea of how fast our country is growing is factored in, things can become even scarier. The table below shows that among the world's most populated countries, the Philippines stands $5^{\text {th }}$ fastest growing.

\begin{tabular}{|l|l|l|}
\hline Rank & Country & Growth Rate \\
\hline 1 & Nigeria & 2.38 \\
2 & Ethiopia & 2.31 \\
3 & Pakistan & 2.09 \\
4 & Bangladesh & 2.09 \\
5 & Philippines & 1.8 \\
6 & Egypt & 1.75 \\
7 & Indonesia & 1.41 \\
8 & India & 1.39 \\
9 & Mexico & 1.16 \\
10 & Iran & 1.1 \\
11 & Turkey & 1.06 \\
12 & Brazil & 1.04 \\
13 & Vietnam & 1.02 \\
14 & United States & 0.91 \\
15 & Thailand & 0.68 \\
16 & China & 0.59 \\
17 & France & 0.35 \\
18 & Japan & 0.02 \\
19 & Germany & -0.02 \\
20 & Russia & -0.37 \\
\hline
\end{tabular}

Table 3: The G rowth Rates of the World's 20 Most-Populated Countries as of 2005.5

With a base of 80 million individuals, a 1.8\% growth rate per annum would mean an additional 1.4 million warm bodies after a year. O ur growth rate of $1.8 \%$ per annum is above the world average growth rate of $1.26 \%$ per annum.

\section{The Philippine Demographics}

What are the more specific contours and behavior of the Philippine demographics? During the Spanish colonial period, the growth rate of the Philippine population had been erratic. It went as high as $2.41 \%$, and as low as $0.5 \%$. This was most probably due to the rebellions and revolution, as well as the backward systems of food production and public healthcare. Starting from the American regime, the growth rate had not dipped below $2.0 \%$. It went as high as $3.1 \%$, and as low as $2.0 \%$. This was most probably due to the improved systems of food production and public healthcare. Based on our past censuses and some extrapolations, our population curve would appear like the following figure:

\footnotetext{
${ }^{4}$ Ibid

5 "Population Growth Rate," in The CIA Wodd Fact Book, <https:/ / www.cia.gov / cia/ publications/ factbook/ fields/ 2002.html>, accessed: 20 April 2007.
} 


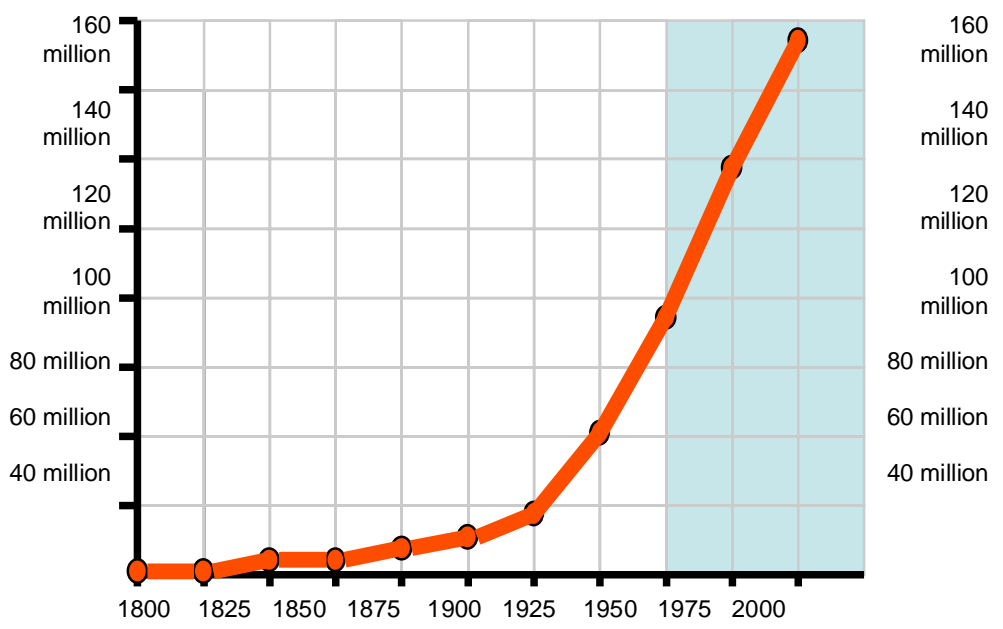

Figure 2: The Philippine Population Curve from 1800 to 2000 with some Forecast up to $2050 .^{6}$

In 2006, the growth rate is said to have dropped to $1.8 \%$ from $2.36 \%$ in 2000. This could be a signal that the country is already entering the third stage of the demographic transition theory, where the birth rate is starting to decline. D emographers, however, predict that by the year 2015, the Philippine population would be 111 million, giving us a density of 373 persons per square kilometer per square kilometer, which is already denser than India's present 358 persons per square kilometer; and that by the year 2040, the population would be 140 million, giving us a density of 470 persons per square kilometer, which is almost double of our present density of 269 persons per square kilometer.

An Asian Development Bank report about the Philippines state: "Population growth in and of itself is not a problem, if resources are available to cope with the additional people requiring public services, employment, housing, and so on ... . But in a country where the budget is already stretched and where poverty is high to begin with, population growth becomes a major issue." 7 It is apparent that the country has problems employing its work force. Although unemployment rate is presently declining, underemployment rate is rising together with overseas employment.

\footnotetext{
6 "Census 2000," in The National Statistics Office <http:// www.census.gov.ph/ census2000 / index.html>, accessed: 20 April 2007.

7 Carlos H. Conde, "Manila's Battle with the Church: Population Control," in Intemational Herald Tribume <http:// www.iht.com/articles/2005/ 04/ 06/ news/ phils.php > , accessed: 20 April 2007.
} 


\section{THE PROBLEM OF POPULATION}

\section{The Power Relations Amidst the Philippine Church, State, and People}

What is the stand of the Philippine Catholic Church on the population problem? The local Church's stand is of course based on the pronouncements of the Vatican. It is important to note at the outset that the Roman Catholic Church has no definitive stand on the problem of over-population. Its more famous stand is merely directed against the use of artificial contraception.

The Church's doctrine against artificial contraception had been developed and advocated by at least four 20th century popes. It was Pope Pius XI (1857-1939) who laid down the principles in 1930, in his encyclical Casti Connubii. He emphasized that the use of artificial contraception is against the law of God and the law of nature. Pope Pius X II (1876-1958) clarified in 1951 that the faithful may resort to the natural, or the rhythm, method if indeed they have a good and legitimate reason to limit the size of their family. In 1958, he stated that women may even use the birth control pill for medical reasons but not for contraception. At a time when the people were expecting more liberal changes after the Second Vatican Council, Pope Paul VI (1897-1978) created a commission to study and review the Church's doctrine on contraception. The commission recommended for the lifting of the contraceptive ban. However in 1968, with the encyclical letter H umanae V itae, Pope Paul VI reasserted the doctrine against artificial contraception. Pope John Paul II (1920-2005), while still a Polish Cardinal mused about the problem of over-population and the profound importance of birth control. In 1978, he referred to the controversy over contraception as a "struggle for the value and meaning of humanity itself." However, when he became pope he re-affirmed the Church's position: "the natural regulation of fertility is morally correct; contraception is not morally correct."

Based on the doctrines of the Vatican and with some keen observations on the local circumstances and government policy developments, the Philippine Catholic Church came up with at least five important documents on the issue of artificial contraception. ${ }^{8}$ In 1969, the local Church issued the Statement of the Catholic Bishops on Public Policy Regarding Population G rowth Control. This document cast doubt on the reality and magnitude of the population problem and vehemently objected to the idea of family planning as a means of reducing population growth. In 1973, the local Church released the Pastoral $\mathrm{L}$ etter of the $\mathrm{C}$ atholic $\mathrm{H}$ ierarchy of the Philippines on Population Problem and Family L ife. This document followed the Marxist line of thinking that overpopulation is not the cause of poverty, but the inequitable distribution of resources. It condemned the government's use of sterilization. In 1988, Jaime Cardinal Sin (1928-2005) publicized the pastoral letter entitled The Population Question that extolled the value of responsible parenthood and the use of the natural or

\footnotetext{
8 Alejandro N. Herrin, "A Review of Population Policy and Program in the Philippines, 1969-2002," in Philippine Institute for Development Studies, < http:// www3.pids.gov.ph/ ris/ dps/ pidsdps0208.pdf>, accessed: 20 A pril 2007, 32-36.
} 
rhythm method of contraception. In 1990, the Catholic Bishops Conference of the Philippines publicized the document entitled $G$ uiding Principles of the CBCP on Population Control that reiterated the doctrines of the church on contraception. Lastly, in 2001, Cardinal Sin issued the Pastoral Exhortation on Family and Life A dvocacy that again extolled the notion of responsible parenthood and reaffirmed the Catholic Church's doctrine against artificial contraception. As a whole, the local Church does not have a clear and specific stand on the problem of over-population and has the tendency of blaming poverty on the inequitable distribution of resources as well as on the mismanagement of goods due to graft and corruption.

The Philippine government, on the other hand, has an inconsistent stand and policy on the problem of over-population. ${ }^{9}$ Ferdinand Marcos (1917-1989) started with a strong commitment to a population reduction policy that was, however, not fully implemented and that started to wane during the last years of his dictatorship. Seen as a very devout Catholic and as heavily indebted to the Catholic Church for the 1986 EDSA Revolution, Corazon Aquino did not have a definite commitment to a population reduction policy. She, however, recognized population as a problem, but failed to come up with a program to reduce fertility. Fidel Ramos, a non-Catholic, was strongly committed to a population reduction policy. However, his policy statements were ambiguous and tended to camouflaged family planning under the semantic veil of "reproductive health promotion." Like Ramos, Joseph Estrada, was strongly committed to population reduction policy. But again his policy statements were ambiguous and tended to camouflaged family planning under the same semantic veil of "reproductive health promotion." He did not have much impact as his presidency was cut short by the second EDSA Revolution in 2001. Like Aquino, Gloria Macapagal-Arroyo is seen as a very devout Catholic and as heavily indebted to the Catholic Church for the second EDSA Revolution. She has an ambiguous commitment to a population reduction policy. Although her development plan contains strong statements against the high growth rate, her family planning program is again camouflaged under another semantic veil, this time it is "helping the couple achieve their preferred number of children while safeguarding maternal and child health."

Alejandro N. Herrin, in his paper entitled Population Policy in the Philippines, 1969-2002, points out that the inconsistencies and ambiguities of the population policies from Marcos to Arroyo are brought about by the consistent "opposition to such a policy by the politically influential Catholic Church hierarchy." 10 If the dictator Marcos bowed to the local Church on this matter, how much political will can we expect from other presidents who were having their incumbencies after the first ED SA Revolution, when the local Church had become even more powerful.

Thus, on one hand, we have a government that is keenly aware of the problems attendant to a huge and fast growing population. But, on the other

\footnotetext{
${ }^{9}$ Ibid., 28-30.

${ }^{10}$ Ibid., 30.
} 


\section{THE PROBLEM OF POPULATION}

hand, we have a very powerful Catholic Church that consistently pressures our government to refrain from framing up an effective fertility reduction program. But what about the Filipino people, what are its sentiments concerning this thorny issue? In a 2007 survey conducted by Pulse Asia it was revealed that $89 \%$ of its respondents wants the government to finance family planning dissemination and procedures that would cover even the stuff banned by the Catholic Church such as the pills, IUD s, condoms, and sterilizations. ${ }^{11}$

When compared to the results of the National Demography Survey of 1968, 1973, 1983, 1988, 1993 and 1998, as well as the results of the Social Weather Station surveys of 1991, 1992, 1993, 1995 and 2000, this Pulse Asia finding suggests that there is a growing number of Filipinos who favor a more effective and clear-cut government policy on population. ${ }^{12}$ Herrin, in the same paper, Population Pdioy in the Philippines, 1969-2002, comments: "Why policymakers in both the executive branch and in Congress do not seem to heed these views in crafting an acceptable and consistent population policy can only mean that the influence of the Catholic Church hierarchy, as viewed from the policymakers' standpoint, is much stronger." This is understandable since the people, represented by the respondents of the surveys mentioned, are not politically organized and structured. Whereas the Church with its hierarchy, ordained leaders, dioceses, parishes, schools and lay organizations can be viewed as a single powerful entity that can mobilize a huge political action in a matter of days or even hours.

We can visualize the circuitry of power amidst the Philippine Church, state and people concerning the problem of population as a three-cornered configuration. Ideally, power and communication should circulate freely through and around them.

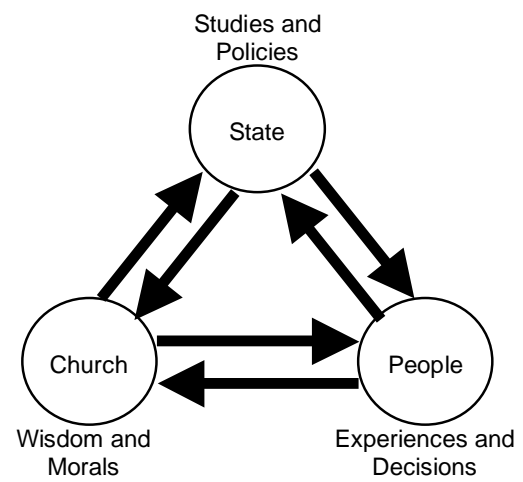

Figure 3: The Idealized Three-Cornered Circuit of Power and Communication amidst the Philippine Church, State and People

11 See Kate Pedroso, "Survey: 9 out of 10 Pinoys Support Birth Control," in The Philippine Daily Inquirer, 14 March 2007, <http:// newsinfo.inquirer.net/ inquirerheadlines/ nation/view article.php?article id=60323> , accessed: 20 April 2007.

${ }^{12}$ Cf. Herrin, qp at., $36-37$. 
But if we analyze the actual flow of power and communication among the three key elements, we will notice that: 1) the flow of power and communication from the Church to the state had been very effective as proven by the state's failure to come up with an effective fertility reduction program; while 2) the flow of power and communication from the state to the Church had not been effective as proven by the state's failure to convince the Church to cooperate in solving the country's population problem; while 3) the flow of power and communication from the Church to the people had not been effective, as the surveys show that the Church had not been successful in convincing the people to abide with its doctrine against contraception; while 4) in the hierarchical structure and dogmatic nature of the Catholic Church, the flow of power and communication from the people to the Church is something that is not expected; while 5) the flow of power and communication from the state to the people had not been very effective due to the state's lack of a clear and effective fertility reduction program; and 6) the flow of power and communication from the people to the state had not been effective, for even with the growing majority of Filipinos favoring that the government frame up a more effective fertility reduction program, no such program emerged.

In the last analysis, the existing paradigm of the circuitry of power and communication amidst the Philippine Church, state and people would appear like the diagram below, where the only significant flow of power and communication is the Church's imposition of its non-negotiable doctrine on the state.

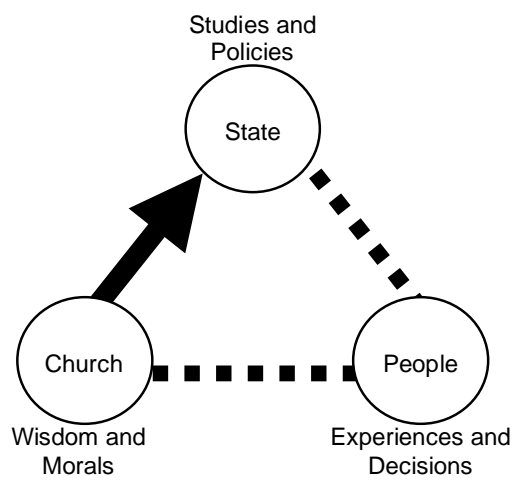

Figure 4: The Actual Three-Cornered Circuit of Power and Communication amidst the Philippine Church, State and People

Although the local church thinks that it is successful in curtailing the state's move to formulate a more effective fertility reduction program, the paradigm of power and communication that it enters into is not a very effective one, both structurally speaking and in the long run. First, the mission of the Church is to evangelize the people and not the state. Second, the Church failed to thoroughly indoctrinate the people on the wisdom of $\mathrm{H}$ umanae $\mathrm{V}$ itae 


\section{THE PROBLEM OF POPULATION}

as manifested by the various surveys. Third, the Church paralyzed the state and rendered it unable to proactively find solutions to its worsening population problem. Fourth, in such a paradigm, the Church dons the mask and image of a bully, and sooner or later this would most probably generate the feelings of resentment among the people in general. Fifth, the Church tends to close itself from the rich data and information coming from the people and from the state's demographic and empirical studies. Sixth, the paradigm excludes the valuable processes of dialogue and consensus building. Seventh, hiding the artificial contraceptives from the people is not the answer to the onslaught of contraceptive mentality, but the formation of strong Christian conscience that says yes to responsible parenthood and no to artificial contraception and antinatalism. Eight, the Church's stand is a little inconsistent, for whereas it is so vehement in denouncing artificial contraception, it remained complacent against the inequitable distribution of goods and graft and corruption. If the Church suggests that it is not over-population which is the cause of poverty, but the inequitable distribution of goods and graft and corruption, it should as vehemently denounce the state's inaction with regards to the minimum wage increase, land reform, and the continued presence of pork barrel among other things.

Noticing the fundamental inefficiency of such a paradigm, Bishop Antonio Ledesma of Ipil, Zamboanga, in 2002, came up with a pastoral letter, entitled Natural Planning A Pastaral Approach In this document, he suggested that the Church modify its position of non-critical collaboration into a principled collaboration.

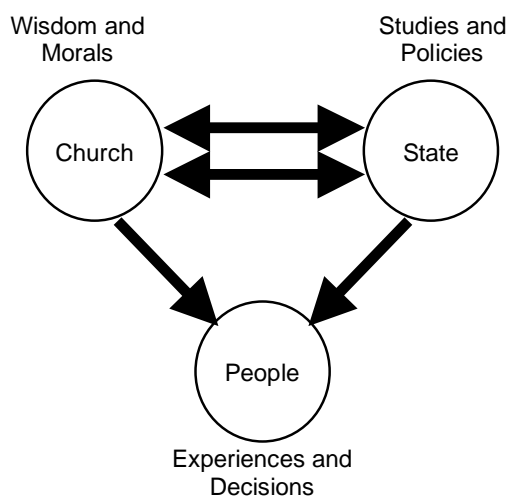

Figure 5: Ledesma's Paradigm of Principled Collaboration

According to Herrin, this paradigm of principled collaboration had actually been tested and implemented by the archdiocese of LingayenDagupan, under Archbishop Oscar Cruz, and the provincial government of Pangasinan. Compared to the previous paradigm where the circuit of power and communication is very limited, Ledesma's paradigm of principled collaboration is definitely superior. However, the paradigm of principled 
collaboration still has some imperfections. First of this is its tendency to exclude the people in the dialogue and consensus building between the Church and the state. Second of this is the Church's limitation of the state's freedom to address the problem of over-population. Third of this is the Church's direct engagement with matters that are political by nature.

\section{The Alternative Paradigm of Power Relations in the Encyclical Deus Caritas Est}

The problem of over-population is a social and political problem in as far as the state is concerned, and a moral and ethical problem in as far as the Church is concerned. The Church has the duty to indoctrinate the people with what it thinks is the moral and ethical conduct. But should it go as far as directly pressuring the government to refrain from finding its own secular solution to such a social and political problem? Is there a better paradigm of power relations than the prevalent critical non-collaboration as well as Ledesma's principled collaboration?

I believe that the answers to these questions can be found in Pope Benedict XVI's encyclical letter Deus Caritas Est, a document that attempts to present a short synthesis of the social teachings of the Church, as well as a template on how the Church should engage itself with the inevitable sphere of politics. The encyclical, although it deals with the nature of Christian love, as its title suggests, contains a very radical political philosophy that ventures into that modern/ postmodern region of discourse ethics, an ethical system that is founded on dialogue and consensus building. In the paper "A Habermasian Reading of the Political Philosophy Contained in the Encyclical Ders Caritas Est," I explored the boldness of this document by marking its points of convergence with the atheistic, secular, critical and dialogical philosophy of Jürgen Habermas. ${ }^{13}$

One of the important questions raised by the encyclical's political philosophy is "who should be responsible in achieving/ establishing justice?" In addressing such question, Pope Benedict XVI returns to the Biblical distinction between "what belongs to Caesar and what belongs to God." The Encyclical states that the attainment of justice is the primary concern of the state and not of the Church. Politics, or the transaction between the state and the people, should be founded in justice and should work for justice.

However, the Holy Father makes a dramatic qualification at this point. Due to the immediate connection between justice and ethics/morals, the Church also should not just stand back and watch whatever political actions the state and the people transact. Just as the prophetic figure of Jesus speaks when it comes to ethical and moral questions, the Church also has to speak when it comes to the question of justice. The Encyclical suggests that the Church should form the faithful into enlightened, ethical, moral, and charitable

\footnotetext{
${ }^{13}$ See F.P.A. D emeterio, "A Habermasian Reading of the Political Philosophy of the Encyclical Das Canitas Est," in Saientia(2006).
} 


\section{THE PROBLEM OF POPULATION}

statesmen and people who will then be responsible in establishing a just and humane society.

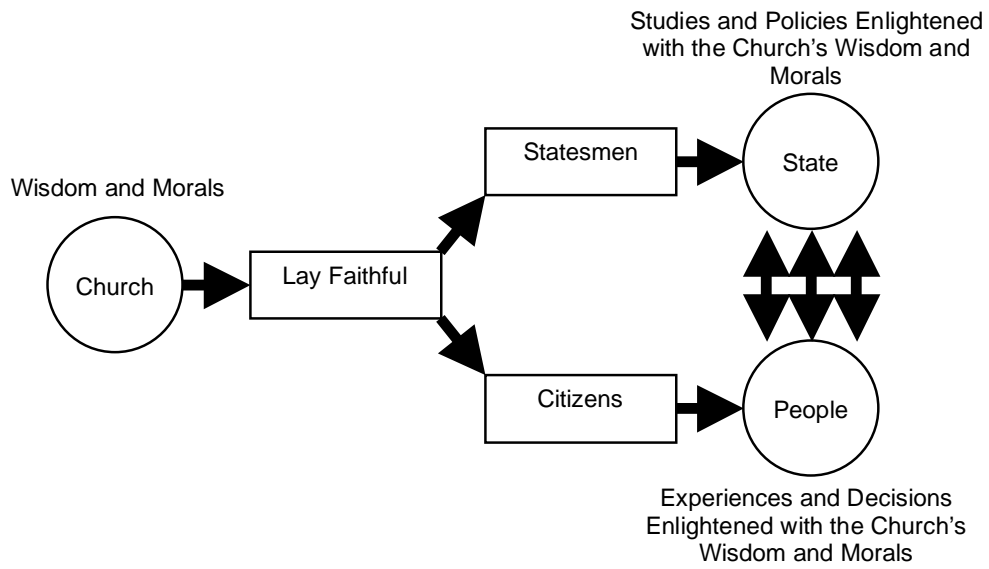

Figure 6: Pope Benedict XVI's Non-Intrusive Paradigm

The Church should not plunge itself in the middle of the dialogue between the state and the people, for it has a more radical task of preparing the faithful statesmen and citizens for such a dialogue.

There are, therefore, at least four paradigms of power relations amidst the Church, state, and people: 1) the idealized three-cornered circuitry; 2) the actual three-cornered circuitry, which we may call the paradigm of critical noncollaboration; 3) Ledesma's paradigm of principled collaboration; and 4) Benedict XVI's non-intrusive paradigm.

Pope Benedict XVI's model might be difficult for the Church to implement for the reason that it requires long-ranged and intensive work. But it is definitely superior in the sense that it maximizes the processes of dialogue and consensus building and at the same time safeguards the integrity of the Church from being tarnished by any direct involvement in the political transaction.

As for the question: what could be the solution to the problem of over-population which would be acceptable to the Church, the state, and the people? The answer for this can only be found after a thorough and sincere dialogue between the state and the people who are both enlightened with the wisdom and morality of the Catholic Church.

D epartment of Philosophy, San Beda College, Philippines 


\section{References Cited}

"Casti Connubii: Encyclical of Pope Pius XI on Christian Marriage," in The

H oly Se,

<http:/ / www.vatican.va/ holy father/ pius xi/ encyclicals/ documents/ h f p-xi enc 31121930 casti-connubii en.html>, accessed: 20 April 2007.

"Census 2000," in The National Statistics Offiœ, <http:// www.census.gov.ph/ census2000 / index.html>, accessed: 20 April 2007.

Conde, Carlos H., "Manila's Battle with the Church: Population Control," in International $\mathrm{H}$ erald Tribune, 07 Apirl 2005, <http:// www.iht.com/ articles/ 2005/ 04/ 06/ news/ phils.php>, accessed: 20 A pril 2007.

Curran, Charles, ed., Contraœption: A uthority and D issent (New York: Herder and Herder, 1969).

Demeterio, F.P.A., "A Habermasian Reading of the Political Philosophy of the Encyclical D eus Caritas E st," in Scientia (2006). Also available online in Dr. F.P.A. Demeterio's Philosophy and Cultural Theory Page, $<$ http:/ / feorillodemeterio.googlepages.com/ habermasbenedict>, accessed: 20 A pril 2007.

Demeterio, F.P.A., "Critical Hermeneutics," in the D iwatao, <http:// www. geocities.com/philodept/ diwatao/ critical_hermeneutics.htm>, accessed: 20 A pril 2007.

Esguerra, Christian, "Catholic Bishops Defend Natural Family Planning Advocacy," in The Philippine Daily Inquirer, 01 January 2007, $<$ http:// newsinfo.inquirer.net/ breakingnews/ nation/ view article.php?article id=42482>, accessed: 20 April 2007.

Herrin, Alejandro N., "A Review of Population Policy and Program in the Philippines, 1969-2002," in Philippine Institute for Development Studies, <http:// www3.pids.gov.ph/ ris/ dps/ pidsdps0208.pdf>, accessed: 20 April 2007.

"H umanae V itae: Encyclical of Pope Paul VI on the Regulation of Birth. 25 July 1968," in The Holy Se, <http:/ / www.vatican.va/ holy father/ paul vi/ encyclicals/ documents/ h f p-vi enc 25071968 humanae-vitae en.html>, accessed: 20 April 2007.

Pedroso, Kate, "Survey: 9 out of 10 Pinoys Support Birth Control," in The Philippine Daily Inquirer, 14 March 2007, $<$ http:/ / newsinfo.inquirer.net/ inquirerheadlines/ nation/view article.php?article id=60323> , accessed: 20 April 2007.

"Population Growth Rate," in The CIA World Fact Book, <https:// www.cia.gov/ cia/ publications/ factbook/ fields/2002.html>, accessed: 20 April 2007. 


\section{THE PROBLEM OF POPULATION}

Rao, V. K., Population Education (New Delhi: APH Publishing Corporation, 2004).

Weeks, John, Population: An Introduction to Concepts and Issues Ninth Edition (Belmont, California: Wadsworth, 2005).

"World Population Prospects," in GeoHive Gldbal Statistics $<$ http:// www.geohive.com/ earth/ pop prospects.aspx >. 